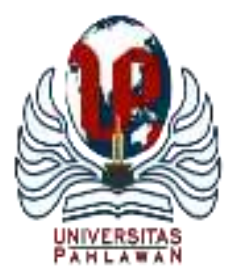

Edukatif : Jurnal Ilmu Pendidikan Volume 3 Nomor 6 Tahun 2021 Halm 4145 - 4151

EDUKATIF: JURNAL ILMU PENDIDIKAN

Research \& Learning in Education

https:/ledukatif.org/index.php/edukatif/index

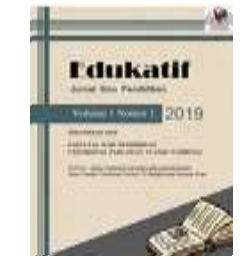

\title{
Persepsi Mahasiswa Terhadap E-Learning Berbasis Zoom Meeting pada Mata Kuliah Telaah Kurikulum Sekolah
}

\author{
Martiani $^{凶}$ \\ Universitas Dehasen Bengkulu, Indonesia \\ E-mail : annie.phaph@unived.ac.id
}

\begin{abstract}
Abstrak
E-learning merupakan alternatif pembelajaran ditengah masa pandemi, salah satunya dengan menggunakan aplikasi Zoom meeting yang merupakan salah satu media pembelajaran. Tujuan dari penelitian ini yaitu untuk mengetahui persepsi mahasiswa terhadap pembelajaran during dengan menggunakan aplikasi zoom meeting. Metode penelitian yang digunakan adalah metode penelitian deskriptif dengan pendekatan kuantitatif. Teknik pengumpulan data dilakukan dengan menggunakan kuesioner berbasis Google Form yang dapat diisi secara online. Kuesioner terdiri atas tiga bagian yaitu proses belajar mengajar, kapabilitas (kompetensi dosen), dan sarana dan prasarana dengan total 13 butir pertanyaan. Subjek yang digunakan pada penelitian ini sebanyak 57 mahasiswa, yaitu mahasiswa semester III program studi pendidikan jasmani. Hasil pembahasan mengenai persepsi mahasiswa mengenai pembelajaran during menggunakan aplikasi zoom pada aspek pertama yaitu aspek belajar mengajar yaitu dengan rata-rata 3.53. pada aspek kedua yaitu aspek kompetensi dosen yaitu dengan rata-rata 3.88. Pada aspek ketiga yaitu aspek sarana dan prasarana yaitu dengan rata-rata 3.54. Disimpulkan bahwa persepsi mahasiswa mengenai pembelajaran during menggunakan aplikasi zoom meeting diperoleh data rata-rata 3.65 yaitu dengan kategori baik.
\end{abstract}

Kata Kunci: E-Learning, Zoom Meeting.

\begin{abstract}
E-learning is alternative learning during a pandemic, one of which is by using the Zoom meeting application which is one of the learning media. The purpose of this study is to determine student perceptions of learning during using the zoom meeting application. The research method used is a descriptive research method with a quantitative approach. Data collection techniques are carried out using a Google Form-based questionnaire that can be filled out online. The questionnaire consists of three parts, namely the teaching and learning process, capability (lecturer competence), and facilities and infrastructure with a total of 13 questions. The subjects used in this study were 57 students, namely third-semester students of the physical education study program. The results of the discussion regarding students' perceptions of learning during using the zoom application in the first aspect, namely the teaching and learning aspect, with an average of 3.53. in the second aspect, namely the aspect of lecturer competence, with an average of 3.88. The third aspect, namely the aspect of facilities and infrastructure, with an average of 3.54. It was concluded that students' perceptions of learning during using the zoom meeting application obtained an average data of 3.65, namely in the good category.
\end{abstract}

Keywords: E-Learning, Zoom Meeting.

Copyright (c) 2021 Martiani

$\triangle$ Corresponding author:

Email : annie.phaph@unived.ac.id

DOI : https://doi.org/10.31004/edukatif.v3i6.1414

ISSN 2656-8063 (Media Cetak) ISSN 2656-8071 (Media Online)

Edukatif : Jurnal Ilmu Pendidikan Vol 3 No 6 Tahun 2021 p-ISSN 2656-8063 e-ISSN 2656-8071 
4146 Persepsi Mahasiswa Terhadap E-Learning Berbasis Zoom Meeting pada Mata Kuliah Telaah Kurikulum Sekolah - Martiani

DOI: https://doi.org/10.31004/edukatif.v3i6.1414

\section{PENDAHULUAN}

Pendidikan merupakan upaya atau proses yang dilakukan seseorang untuk memperoleh pengetahuan, keterampilan, kebiasaan, dalam kehidupan. Proses belajar mengajar sebelumnya dilakukan secara langsung tatap muka tetapi saat ini wabah Covid-19 sudah melanda dunia termasuk negara Indonesia. World Health Organization (WHO), mengemukakan bahwa Covid-19 adalah infeksi pada saluran pernapasan manusia serta penyakit yang menular. Melalui Surat Edaran Dirjen Dikti Kementerian Pendidikan dan Kebudayaan Nomor 1 Tahun 2020 tentang pencegahan penyebaran corona virus disease (COVID-19) di Perguruan Tinggi. Dalam surat edaran tersebut berisi tentang himbauan agar perguruan tinggi melaksanakan pembelajaran jarak jauh sesuai dengan kondisi masing-masing, dan menyarankan mahasiswa untuk melakukan pembelajaran dari rumah. Seorang pendidik diharapkan memiliki kecakapan dalam melaksanakan kegiatan proses belajar mengajar dengan penguasaan materi pelajaran, ketepatan kecakapan pemilihan pengunaan materi mengajar, ketepatan pemilihan metode dan media pembelajarn serta sumber belajar yang efektif.

Proses pembelajaran merupakan proses komunikasi. Dalam suatu proses komunikasi selalu melibatkan tiga komponen pokok, yaitu pengirim pesan, penerima pesan dan pesan itu sendiri yang merupakan materi pelajaran. Kegagalan komunikasi sering terjadi pada proses pembelajaran, artinya materi pelajaran atau pesan yang disampaikan guru tidak dapat diterima oleh siswa dengan optimal, artinya tidak seluruh materi pelajaran dapat dipahami dengan baik oleh siswa; lebih parah lagi siswa sebagai penerima pesan salah menangkap isi pesan yang disampaikan. Untuk menghindari semua itu, maka guru dapat menyusun strategi pembelajaran dengan memanfaatkan berbagai media dan sumber belajar sebagai perantara yang mampu memberi makna yang sama antara komunikator dengan komunikan (Musfiqon, 2012).

Media merupakan segala sesuatu yang dapat digunakan untuk menyalurkan pesan dari pengirim ke penerima sehingga dapat merangsang pikiran, perasaan, perhatian dan minat serta perhatian siswa sedemikian rupa sehingga proses belajar terjadi (Sadiman, 2003). Hal tersebut sependapat dengan Heinich dalam (Sutirman, 2013) yang mengartikan media sebagai apa saja yang dapat menyalurkan informasi dari sumber ke penerima informasi. Sutirman (2013: 15) menyatakan bahwa dalam konteks pendidikan, media biasa disebut sebagai fasilitas pembelajaran yang membawa pesan kepada pembelajar. Dapat disimpulkan bahwa media adalah alat bantu yang digunakan untuk menyalurkan pesan atau informasi dari pengirim ke penerima.

Perilaku manusia diawali dengan adanya penginderaan atau sensasi biasa disebut persepsi. Persepsi pada hakikatnya adalah sebuah proses kognitif yang dialami oleh setiap orang dalam memahami informasi tentang lingkungannya, baik lewat penglihatan, pendengaran, penghayatan, perasaan, maupun penciuman (Thoha, 2005). Kunci dalam memahami persepsi ialah terletak pada pengenalan bahwa persepsi itu sendiri merupakan suatu penafsiran yang unik terhadap situasi. Melalui persepsi manusia terus-menerus mengadakan hubungan dengan lingkunganya. Hubungan tersebut dilakukan melalui inderanya, yaitu indera penglihat, pendengar, peraba, perasa, dan pencium (Slameto, 2010).

Persepsi merupakan suatu proses kognitif dasar dalam kehidupan manusia. Persepsi adalah penelitian tentang bagaimana mengintegrasikan sensasi kedalam sebuah objek, dan bagaimana selanjutnya menggunakan persepsi tersebut untuk mengenali dunia (persepsi adalah hasil dari proses perseptual), (Walgito, 2007) menyebutkan bahwasannya persepsi merupakan suatu proses yang terlebih dahulu diproses oleh penginderaan, yaitu merupakan proses dimana stimulus diterima oleh individu melalui alat indera yang juga disebut dengan proses sensoris. Dari berbagai pengertian dan pendapat para ahli tentang persepsi di atas, maka dapat diambil kesimpulan bahwa persepsi adalah suatu proses di dalam menginterpretasi atau menafsirkan suatu bentuk stimulus yang diterima oleh alat indera, yang kemudian diteruskan ke otak sehingga terwujud dalam bentuk sikap atau tindakan. 


\section{Persepsi Mahasiswa Terhadap E-Learning Berbasis Zoom Meeting pada Mata Kuliah Telaah}

Kurikulum Sekolah - Martiani

DOI: https://doi.org/10.31004/edukatif.v3i6.1414

E-learning sebagai salah satu alternatif pembelajaran di tengah masa pademi virus corona. Pembelajaran e-learning merupakan pembelajaran dengan memanfaatkan teknologi internet untuk menyampaikan materi dengan cakupan yang luas. Adanya e-learning memungkinkan terjadinya proses pendidikan tanpa melalui tatap muka langsung dan pengembangan ilmu pengetahuan kepada pelajar dan mahasiswa bisa dilakukan dengan mudah. E-learning merupakan pembelajaran jarak jauh yang memanfaatkan internet. E-learning sebagai alternatif pembelajaran ditengah wabah corona virus disease 2019 (Covid-19) karena kekhawatiran penularan virus tersebut. Menurut Rusman dalam (Marhayani, 2021) e-learning memiliki karakteristik, antara lain (a) interactivity (interaktivitas); (b) independency (kemandirian); (c) accessibility (aksesibilitas); (d) enrichment (pengayaan). E-learning memudahkan interaksi antara mahasiswa dengan dosen dalam menyampaikan materi perkuliahan. Mahasiswa dapat mengakses bahan-bahan perkuliahan setaip saat dan dapat saling berbagi informasi.

E-learning dapat dilakukan dengan menggunakan berbagai aplikasi pihak ketiga yang dapat mendukung proses pembelajaran daring seperti Zoom Meeting, Google Classroom, Google Meet, dan CloudX. Hasil survei yang dilakukan oleh Statqoanalytics dalam (Maulana, 2021) menunjukkan bahwa Zoom merupakan aplikasi yang paling banyak digunakan sebagai platform pembelajaran daring. Zoom merupakan aplikasi yang menggabungkan konferensi video, pertemuan online, obrolan, hingga kolaborasi seluler untuk menyediakan layanan konferensi jarak jauh (zoom.us, 2021). Zoom dapat menghadirkan kelas secara virtual sehingga pengajar dan peserta didik dapat bertatap muka secara virtual, melaksanakan proses pembelajaran secara dua arah dan memiliki efektifitas yang sama dengan pembelajaran tatap muka secara langsung (Syarif \& Kholis, 2020). Hal inilah yang membuat aplikasi ini banyak digunakan sebagai sarana belajar mengajar.

\section{METODE PENELITIAN}

Metode penelitian yang digunakan adalah metode penelitian deskriptif dengan pendekatan kuantitatif. (Sugiyono, 2008) menjelaskan bahwa penelitian deskriptif yaitu, penelitian yang dilakukan untuk mengetahui nilai variabel mandiri, baik satu variabel atau lebih (independen) tanpa membuat perbandingan, atau menghubungkan dengan variabel yang lain. (Turmuzi, 2021) Penelitian ini menggunakan jenis penelitian kualitatif deskriptif dan dieksplorasikan melalui data kuantitatif. Karakteristik penelitian kualitatif yaitu melakukan penelitian dalam kondisi yang alamiah, langsung ke sumber data, peneliti menjadi instrumen kunci, menyajikan data-data dalam bentuk kata-kata atau gambar dan tidak menekankan angkaangka, melakukan analisis data. Metode penelitian kualitatif ini tidak dimanipulasi oleh peneliti, analisis data berdasarkan fakta-fakta yang ditemukan dilapangan Sugiyono dalam (Yunitasari \& Hanifah, 2020).

Berdasarkan pengertian tersebut dapat disimpulkan bahwa penelitian deskriptif dilakukan dengan cara mencari informasi berkaitan dengan gejala yang ada, dijelaskan dengan jelas tujuan yang akan diraih, merencanakan bagaimana melakukan pendekatannya, dan mengumpulkan berbagai macam data sebagai bahan untuk membuat laporan. Subjek yang digunakan pada penelitian ini sebanyak 46 mahasiswa, yaitu mahasiswa semester III program studi pendidikan jasmani.

Pengumpulan data dalam penelitian ini yaitu dengan kuesioner dengan menggunakan skala likert sebagai alternatif pilihan. Hasil dari data yang diperoleh akan dianalisis menggunakan analisis deskriptif kuantitatif dalam bentuk persentase. Hal ini untuk lebih memudahkan dalam membaca dan memahami data. Runtutan langkah yang dilakukan adalah menghitung skor perolehan tiap indikator. Setelah itu menghitung persentase jawaban dari tiap indikator kemudian ditarik kesimpulan akhirnya. Pedoman dari (Sugiyono, 2011) yaitu "semakin tinggi persentase responden maka semakin baik pula persepsi responden".

Teknik pengumpulan data dilakukan dengan menggunakan kuesioner berbasis Google Form yang dapat diisi secara online. Kuesioner terdiri atas tiga bagian yaitu proses belajar mengajar, kapabilitas (kompetensi dosen), dan sarana dan prasarana dengan total 13 butir pertanyaan. Setiap butir pertanyaan 
4148 Persepsi Mahasiswa Terhadap E-Learning Berbasis Zoom Meeting pada Mata Kuliah Telaah Kurikulum Sekolah - Martiani

DOI: https://doi.org/10.31004/edukatif.v3i6.1414

menggunakan skala ordinal, yaitu: Sangat Tidak Setuju/STS (1), Tidak Setuju/TS (2), Ragu-ragu/RR (3), Setuju/S (4), dan Sangat Setuju/SS (5). Hasil kuesioner dikelompokkan ke dalam interval seperti pada Tabel 1 berikut.

Tabel 1

Kategori Persepsi Mahasiswa

\begin{tabular}{cll}
\hline No & Rentang Skor $(\boldsymbol{\%})$ & Kategori \\
\hline 1 & $1.00-1.80$ & Sangat Buruk \\
\hline 2 & $1.81-2.60$ & Buruk \\
\hline 3 & $2.61-3.40$ & Sedang \\
\hline 4 & $3.41-4.20$ & Baik \\
\hline 5 & $4.21-5.00$ & Sangat Baik \\
\hline & & Sugiyono dalam (Maulana, 2021)
\end{tabular}

\section{HASIL DAN PEMBAHASAN}

Analisis data hasil penelitian mengacu pada tiga aspek penilaian yang digunakan, yaitu aspek belajar mengajar, aspek kompetensi dosen, dan aspek sarana prasarana. Hasil kuisioner yang diisi secara online oleh mahasiswa program studi pendidikan jasmani.

Tabel 2

\section{Hasil Kuisioner Responden}

\begin{tabular}{|c|c|c|c|}
\hline No & Item & Rata-Rata & Kategori \\
\hline \multicolumn{4}{|c|}{ ASPEK BELAJAR MENGAJAR } \\
\hline 1 & $\begin{array}{l}\text { Pelaksanaan Perkuliahan daring dapat diakses secara } \\
\text { mudah. }\end{array}$ & 4.15 & Baik \\
\hline 2 & $\begin{array}{l}\text { Pelaksanaan Perkuliahan daring tepat waktu dan } \\
\text { sesuai dengan jadwal. }\end{array}$ & 3.20 & Sedang \\
\hline 3 & $\begin{array}{l}\text { Perkuliahan secara daring menambah pemahaman } \\
\text { teori dan keterampilan }\end{array}$ & 3.22 & Baik \\
\hline 4 & $\begin{array}{l}\text { Materi yang disajikan secara daring sesuai dengan } \\
\text { Kontrak Perkuliahan/RPS }\end{array}$ & 3.85 & Baik \\
\hline 5 & Kemudahan dalam mengirimkan tugas/laporan & 3.25 & Sedang \\
\hline & Rata-Rata & 3.53 & Baik \\
\hline \multicolumn{4}{|c|}{ ASPEK KAPABILITAS (KOMPETENSI DOSEN) } \\
\hline 1 & $\begin{array}{l}\text { Dosen selalu menemani ketika pembelajaran secara } \\
\text { daring hingga selesai }\end{array}$ & 4.05 & Baik \\
\hline 2 & $\begin{array}{l}\text { Dosen menjelaskan arah dan tujuan dalam setiap } \\
\text { pembelajaran secara daring }\end{array}$ & 4.12 & Baik \\
\hline 3 & $\begin{array}{l}\text { Dosen memberikan kesempatan mahasiswa untuk } \\
\text { bertanya dan berdiskusi }\end{array}$ & 4.18 & Baik \\
\hline 4 & $\begin{array}{l}\text { Dosen memberikan respon terhadap pertanyaan yang } \\
\text { muncul selama perkuliahan secara daring }\end{array}$ & 4.22 & Baik \\
\hline 5 & $\begin{array}{l}\text { Tingkat pemahaman anda secara umum terhadap mata } \\
\text { kuliah yang disajikan secara daring }\end{array}$ & 3.37 & Sedang \\
\hline 6 & $\begin{array}{l}\text { Rerata keaktifan dan attitude Anda selama perkuliahan } \\
\text { secara daring }\end{array}$ & 3.39 & Sedang \\
\hline & Rata-Rata & 3.88 & Baik \\
\hline \multicolumn{4}{|c|}{ ASPEK SARANA DAN PRASARANA } \\
\hline 1 & Materi pada pembelajaran daring tersedia dengan Baik & 3.76 & Baik \\
\hline 2 & $\begin{array}{l}\text { Saya memiliki perangkat/peralatan untuk melakukan } \\
\text { praktikum di rumah sesuai dengan petunjuk yang } \\
\text { diberikan. }\end{array}$ & 3.35 & Sedang \\
\hline
\end{tabular}


4149 Persepsi Mahasiswa Terhadap E-Learning Berbasis Zoom Meeting pada Mata Kuliah Telaah Kurikulum Sekolah - Martiani

DOI: https://doi.org/10.31004/edukatif.v3i6.1414

$\begin{array}{lll}\text { Rata-Rata } & 3.54 & \text { Baik } \\ \text { Rata-Rata Keseluruhan } & 3.65 & \text { Baik }\end{array}$

Dari hasil penelitian diperoleh rata-rata total keseluruhan jawaban responden mengenai persepsi mahasiswa mengenai pembelajaran during menggunakan aplikasi zoom yaitu sebesar 3.65 dengan kategori Baik. Skala persepsi mahasiswa yang diperoleh melalui kuisioner online menunjukkan bahwa penggunaan aplikasi zoom meeting pada proses pembelajaran during termasuk dalam kategori baik ini dapat dilihat dari hasil analisis tiap aspek atau indikator dengan rincian sebagai berikut:

Hasil analisis data diatas menunjukkan hasil persentase persepsi mahasiswa mengenai pembelajaran during menggunakan aplikasi zoom pada aspek atau indikator pertama yaitu aspek belajar mengajar yaitu dengan rata-rata 3.53. Dapat disimpulkan bahwa secara umum persepsi mahasiswa pendidikan jasmani dalam indikator aspek belajar mengajar dikategorikan Baik. Belajar adalah suatu proses yang terjadi pada setiap orang sepanjang hidupnya. Proses belajar terjadi disebabkan adanya interaksi antara seseorang dengan lingkungannya. Oleh karena itu belajar dapat terjadi kapan saja dan dimana saja. Proses belajar mengajar ditandai dengan adanya penyajian materi yang khusus, oleh karena itu materi harus dipersiapkan sedemikian rupa sehingga sesuai untuk mencapai tujuan pembelajaran (Inah, 2015). Materi yang disampaikan pada perkuliahan daring tetap sesuai dengan kontrak perkuliahan dan rencana pembelajaran semester. Hal ini ditunjukkan dengan persepsi mahasiswa dalam kategori baik.

Hasil analisis data diatas menunjukkan hasil persentase persepsi mahasiswa mengenai pembelajaran during menggunakan aplikasi zoom pada aspek atau indikator kedua yaitu aspek kompetensi dosen yaitu dengan rata-rata 3.88. Dapat disimpulkan bahwa secara umum persepsi mahasiswa pendidikan jasmani dalam indikator aspek kompetensi dosen dikategorikan Baik. Proses belajar mengajar antara pendidik dan peserta didik akan semakin baik apabila terdapat komunikasi yang terjalin dengan baik antara keduanya, Malik dalam (Maulana, 2021). Dosen merupakan salah satu faktor eksternal yang mempengaruhi prestasi belajar. Dosen memiliki peranan strategis dalam pelaksanaan setiap upaya peningkatan mutu, relevansi, dan efisiensi pendidikan (Mediawati, 2010).

Hasil analisis data diatas menunjukkan hasil persentase persepsi mahasiswa mengenai pembelajaran during menggunakan aplikasi zoom pada aspek atau indikator ketiga yaitu aspek sarana dan prasarana yaitu dengan rata-rata 3.54. Dapat disimpulkan bahwa secara umum persepsi mahasiswa pendidikan jasmani dalam indikator aspek sarana dan prasarana dikategorikan Baik. Sarana dan prasarana pendidikan harus tersedia semaksimal mungkin guna mendukung pelaksanaan proses belajar mengajar sehingga peserta didik dapat mengikuti proses pembelajaran dengan nyaman dan lancar tanpa adanya kendala. Berdasarkan hasil kuesioner terlihat bahwa dari aspek sarana dan prasarana pembelajaran daring yang dilaksanakan menggunakan Zoom Meeting berada pada kategori baik.

Sarana dan prasarana belajar memberikan manfaat yang berarti bagi keberhasilan proses belajar belajar. Arshad dalam (Jannah \& Sontani, 2018) berpendapat bahwa manfaat sarana dan prasarana belajar adalah sebagai berikut : 1) Pemanfaatan sarana belajar dapat memperjelas pesan dan informasi sehingga dapat memperlancar dan meningkatkan proses dan hasil belajar, 2) Meningkatkan dan menggairahkan perhatian anak sehingga dapat menimbulkan motivasi belajar, interaksi yang lebih langsung antara siswa dan lingkungannya dan memungkinkan siswa untuk belajar sendiri sesuai dengan kemampuan minat, dan 3) Memberikan kesamaan pengalaman kepada siswa tentang peristiwa-peristiwa di lingkungan mereka, serta memungkinkan terjadinya interaksi langsung dengan guru, masyarakat dan lingkungannya, misal melalui karyawisata dan lain-lain. Hasil ini sejalan dengan penelitian (Rosyid, Thohari, \& Lismanda (2020), n.d.) terkait penggunaan Zoom Meeting pada pembelajaran mata kuliah statistika bahwa terdapat fitur recording yang mampu merekam aktifitas pembelajaran daring sehingga dapat dipelajari secara berulang-ulang. 
4150 Persepsi Mahasiswa Terhadap E-Learning Berbasis Zoom Meeting pada Mata Kuliah Telaah Kurikulum Sekolah - Martiani

DOI: https://doi.org/10.31004/edukatif.v3i6.1414

\section{KESIMPULAN}

Pembelajaran during melalui aplikasi zoom meeting dapat memberikan solusi dalam proses pembelajaran during. Hasil pembahasan mengenai pembelajaran mahasiswa dengan menggunakan persepsi mahasiswa mengenai pembelajaran during menggunakan aplikasi zoom meeting diperoleh data yaitu dengan kategori baik.

\section{DAFTAR PUSTAKA}

Inah, E. N. (2015). Peran Komunikasi dalam Interaksi Guru Dan Siswa. Al-TA'DIB: Jurnal Kajian Ilmu Kependidikan, 8(2), 150-167. https://doi.org/10.31332/ATDB.V8I2.416

Jannah, S. N., \& Sontani, U. T. (2018). Sarana dan prasarana pembelajaran sebagai faktor determinan terhadap motivasi belajar siswa (Learning facilities and infrastructure as a factor determinant to student learning motivation). Jurnal Pendidikan Manajemen Perkantoran, 3(1), 63-70. https://doi.org/10.17509/jpm.v3i1.9457

Marhayani, D. A. (2021). Persepsi Mahasiswa STKIP Singkawang terhadap Penggunaan Elearning Berbasis Zoom Meeting. Jurnal Inovasi Penelitian, 1(10), 1-208.

Maulana, H. A. (2021). Persepsi Mahasiswa terhadap Pembelajaran Daring di Pendidikan Tinggi Vokasi: Studi Perbandingan antara Penggunaan Google Classroom dan Zoom Meeting. Edukatif: Jurnal Ilmu Pendidikan, 3(1), 188-195. https://doi.org/10.31004/edukatif.v3i1.259

Mediawati, E. (2010). Pengaruh Motivasi Belajar Mahasiswa dan Kompetensi Dosen terhadap Prestasi Belajar. Dinamika Pendidikan, 5(2), 134-146. https://doi.org/10.15294/DP.V5I2.4922

Musfiqon, M. (2012). Pengembangan Media dan Sumber Pembelajaran. jakarta:Prestasi Pustaka Publisher.

Rosyid, Thohari, \& Lismanda (2020). (n.d.). Retrieved September 6, 2021, from https://www.google.com/search?q=Rosyid\%2C+Thohari\%2C+\%26+Lismanda+(2020)\&rlz=1C1GCEA _enID937ID937\&oq=Rosyid\%2C+Thohari\%2C+\%26+Lismanda+(2020)\&aqs=chrome..69i57.854j0j4 \&sourceid=chrome\&ie $=$ UTF- 8

Sadiman, A. S. (2003). Media Pendidikan. Jakarta: Raja Grafindo Persada.

Slameto. (2010). Belajar Dan Faktor-Faktor Yang Mempengaruhinya Cet. IV. Jakarta: Rineka Cipta. https://adoc.pub/slameto-belajar-dan-faktor-faktor-yang-mempengaruhinya-jakar.html

Sugiyono. (2008). Metode Penelitian Pendidikan:(Pendekatan Kuantitatif, Kualitatif dan $R \& D$ ). Bandung: Alfabeta.

Sugiyono. (2011). Metode Penelitian Kuantitaif Kualitatif dan $R \& B$. Bandung: Alfabeta. https://www.google.com/search?q=Sugiyono\%2C+2011.+Metode+Penelitian+Kuantitaif+Kualitatif+da $\mathrm{n}+\mathrm{R}+\% 26+\mathrm{B} \% 2 \mathrm{C}+$ Bandung\%3A+Alfabeta.\&rlz=1C1GCEA_enID937ID937\&oq=Sugiyono\%2C+201 1.+Metode+Penelitian+Kuantitaif + Kualitatif + dan $+\mathrm{R}+\% 26+\mathrm{B} \% 2 \mathrm{C}+\mathrm{Bandung} \% 3 \mathrm{~A}+$ Alfabeta. \&aqs $=\mathrm{chr}$

Sutirman. (2013). Pembelajaran Inovatif Media Dan Model-Model Pembelajaran Inofatif. In Yogyakarta: Graha Ilmu.

Syarif, S., \& Kholis, N. (2020). Keaktifan Siswa dalam Pembelajaran Hafalan Al-Qur'an Menggunakan Zoom: Studi Pada Siswa Kelas 8 Smp Ar-Rahmah Malang. Al-Tadzkiyyah: Jurnal Pendidikan Islam, 11(2), 275-293. https://doi.org/10.24042/ATJPI.V11I2.7106

Thoha, M. (2005). Motivasi Dalam Organisasi: Perilaku Organisasi Konsep Dasar dan Aplikasinya. In Jakarta: Rajawali.

Turmuzi, M. (2021). Analisis Kompetensi Profesional dan Pedagogik Mahasiswa Pendidikan Matematika Dalam Implementasi Kurikulum 2013. Edukatif: Jurnal Ilmu Pendidikan, 3(2), 341-354.

https://doi.org/10.31004/edukatif.v3i2.301 
4151 Persepsi Mahasiswa Terhadap E-Learning Berbasis Zoom Meeting pada Mata Kuliah Telaah Kurikulum Sekolah - Martiani

DOI: https://doi.org/10.31004/edukatif.v3i6.1414

Walgito, B. (2007). Psikologi Sosial Suatu Pengantar. Yogyakarta : Andi Offset.

Yunitasari, R., \& Hanifah, U. (2020). Pengaruh Pembelajaran Daring Terhadap Minat Belajar Siswa pada Masa COVID-19. Jurnal Ilmu Pendidikan, 2(3), 232-243. https://doi.org/10.31004/edukatif.v2i3.142 